\title{
Dowody izeznania. Świadectwa o Zagładzie w pierwszych latach powojennych
}

Agnieszka Haska

TEKSTY DRUGIE 2018, NR 3, S. 361-372

DOI: $10.18318 /$ td.2018.3.25

E stera Bieżuner zaczyna mówić. Szybko, gorączkowo, zawile. Odbiega od tematu, powraca, wymienia imiona, nazwiska przyjaciół, krewnych, znajomych, miesza daty, fakty ważne z najbłahszymi drobiazgami. [...] ręce zaciska kurczowo, łzy spływają z oczu. Mniejsza o logikę, o ścisłość faktów. To ból dyktuje jej te słowa, męki, jakie przeżyła nie pozwalają jasno formułować myśli"1. Tak swoje spotkanie z Esterą Bieżuner relacjonowała Stefania Beylin, tłumaczka i pisarka, która w 1945 roku została zatrudniona przez Wojewódzką Żydowską Komisję Historyczną w Warszawie do przeprowadzania wywiadów z ocalałymi z Zagłady Żydów i spisywania ich relacji. Estera Bieżuner w krótkiej i przejmującej opowieści relacjonuje swoje losy; od wybuchu wojny, przez getto warszawskie, wyjście na tzw. stronę aryjską, śmierć całej rodziny, w tym obu córek, ukrywanie się dzięki fałszywym dokumentom - aż do wyzwolenia. Nie było to jednak spotkanie obiektywnej, bezstronnej protokolantki ze świadkiem - Beylin bowiem sama ukrywała się podczas wojny

1 Archiwum Żydowskiego Instytutu Historycznego (dalej AŻıH), Relacje, sygn. $301 / 468$, k.2.

Agnieszka Haska

- kulturoznawczyni i socjolożka, członkini Centrum Badań nad Zagładą Żydów IFIS PAN. Autorka licznych publikacji dotyczących Zagłady Żydów oraz kultury popularnej dwudziestolecia międzywojennego, m.in. książek Jestem Żydem, chcę wejść. Hotel Polski w Warszawie, 1943 (2006) oraz Hańba! Opowieści o polskiej zdradzie (2018).Kontakt: ahaska@ifispan.waw.pl 
na aryjskich papierach, najpierw w Milanówku, a potem w majątku Karskie koło Sokołowa Podlaskiego. W tym przypadku świadka wysłuchuje więc inny świadek.

We współczesnej refleksji o świadectwach o Zagładzie można wyróżnić wiele wątków. Oprócz podstawowych pytań dotyczących samej figury świadka dotyczą one rozważań na temat różnego typu gotowych, ugruntowanych narracji, reprezentacji, prawdziwości i falsyfikacji świadectwa czy wreszcie różnych wymiarów obecności świadka. Wydaje się jednak, że dla pełniejszej współczesnej refleksji nad świadkiem i świadectwem należy cofnąć się do momentu tworzenia się tej narracji i zadać pytanie, co znaczyło bycie świadkiem w pierwszych latach tuż po wojnie? Jak rozumiano świadectwo i narrację o Zagładzie? Odpowiedź na to pytanie przynieść mogą relacje zbierane przez Centralną Żydowską Komisję Historyczną w latach 1944-1947, przechowywane obecnie w Archiwum ŻIH pod sygnaturą 301. Zbiór ten, poszerzany w późniejszych latach i zawierający obecnie ponad siedem tysięcy relacji w różnych językach, do dziś służy jako jedno z podstawowych źródeł do badania Zagłady. Rzadko jednak analizuje się go pod kątem nie tyle świadectwa stricte historycznego, co świadectwa jako takiego, dostarczającego wiedzy o kształtowaniu narracji o Zagładzie tuż po wojnie.

Jak bowiem pokazuje przykład pierwszych opisów Zagłady, publikowanych latem 1944 roku po wyzwoleniu obozu na Majdanku, to nie relacje świadków miały być dowodami niemieckich zbrodni. Jednym z pierwszych dziennikarzy, który zobaczył wyzwolony Majdanek, był Jerzy Putrament; pierwsza część jego reportażu z obozu ukazała się 5 sierpnia 1944 roku na łamach organu PKWN „Rzeczpospolita”2. Tekst rozpoczyna się od opisu pola kapusty, rosnącej wokół terenów obozowych, która „zasadzona została na potwornych cmentarzyskach, na trupach setek pomordowanych tu ludzi". Dalej następuje opis krematorium: „Za ostatniem «polem» [...] stoją spalone ściany jakiegoś budynku, którego przeznaczenie na pierwszy rzut oka wydaje się niejasne: piekarnia? Wysoki, kilkumetrowy, gruby, kwadratowy komin. Obok ściany z betonu, czasem niskie, czasem naturalnej wielkości. Kręci się tu sporo ludzi. Wszyscy mają przy ustach i nosie chustki. Zaglądamy przez pierwszą ścianę: kupa szmat, podartych marynarek, spodni i jeszcze czegoś brudnego. Zaglądamy do następnej ubikacji. Tu leżą trupy. Są w tem stadium,

2 Druga część ukazała się w następnym numerze z 6 sierpnia 1944 roku. Inne teksty na ten temat to: Trzy dokumenty, "Rzeczpospolita” 1944 nr 6 z 7 sierpnia, s. 3i J. Putrament Niemcy na Majdanku, „Rzeczpospolita” 1944 nr 7, 9 sierpnia, s. 3. 
kiedy w nich niema już nic ludzkiego. Są odrażające. Szczątki czegoś gnijącego sterczą między żebrami i przy kościach udowych. Budynek był zbudowany z betonu i pokryty deskami. Przeszły tędy litościwe kobiety i rzuciły wiązanki kwiatów. Kwiaty zgniły i na zwłokach zostały z nich tylko długie, zczerniałe włókna czegoś także przerażającego"3. Obok są piece, na rusztach których Putrament dostrzega trupy dzieci. Za krematorium zaś - rowy, w których kopią jeńcy niemieccy, odkrywając zwłoki pomordowanych tu ludzi.

Majdanek był pierwszym wyzwolonym tak dużym obozem śmierci i był pierwszym przykładem niewyobrażalnego, które miało stać się symbolem zbrodni popełnianych przez nazistów, a w węższym planie - zagłady Żydów. Ale powyższe cytaty pokazują także inny problem z opowiadaniem o Zagładzie - dla Putramenta oraz innych dziennikarzy, którzy w sierpniu 1944 roku pisali relacje z Majdanka ważniejsze było to, co sami widzieli na terenie byłego obozu - i tak to opowiadali czytelnikom ${ }^{4}$. O zbrodniach zaświadczyć miały - jak w amerykańskim magazynie „Life”, który w numerze z 28 sierpnia 1944 roku zamieścił krótką korespondencję z Lublina - zdjęcia masowych grobów, pieców krematoryjnych, szkieletów oraz góry butów, pozostałych po ofiarach. Relacje naocznych świadków miały dla nich znaczenie drugorzędne, jeśli nie żadne. Putrament co prawda przytacza opowieść felczera-Białorusina, jeńca z Majdanka, ale więcej miejsca poświęca oglądanym butom pomordowanych. Dodatkowo Majdanek nie jest miejscem zagłady Żydów, a po prostu mężczyzn, kobiet i dzieci. U Putramenta Żydzi pojawiają się raptem raz, kiedy pisze o barakach wznoszonych przez „więźniów-Żydów”. Nawet w opisie „krwawej środy”, czyli rozstrzelania 18 tysięcy Żydów 3 listopada 1943 roku w ramach akcji Erntefest ofiary to po prostu „kobiety i mężczyźni”" Nie zmienia to jednak faktu, że na początku to rzeczy są dowodami, nie ci, którzy przeżyli. Ale same rzeczy czy fotografie nie wystarczą - stąd na łamach „Rzeczpospolitej” pojawiają się anonimowe relacje świadków ${ }^{6}$.

Relacje świadków staną się podstawą powołania 29 sierpnia 1944 roku w Lublinie Żydowskiej Komisji Historycznej. W jej pracach uczestniczyli

3 J. Putrament Fabryka śmierci w Majdanku, "Rzeczpospolita” 1944 nr 3 z 5 sierpnia, s. 3.

4 Zob. B. Zelizer Remembering to Forget: Holocaust Memory Through the Camera's Eye, University of Chicago Press, Chicago 2000, s. 54.

5 J. Putrament Fabryka śmierci w Majdanku cz. 2, s. 3.

6 J.G. Ostatnie dni Majdanka, nr 10 z 12 sierpnia, s. 3; J.G. Droga. Z pamiętnika więźnia Majdanka, nr 11 z 13 sierpnia, s. 3; C.K., Cegielnia, nr 12 Z14 sierpnia, Mussfeld. Typy niemieckie, nr 15 Z 17 sierpnia, C.K. Higiena, $\mathrm{nr} 16 \mathrm{z} 18$ sierpnia. 
ludzie związani z powołanym 10 sierpnia Komitetem Żydowskim oraz Związkiem Literatów, Dziennikarzy i Artystów Żydowskich; Marek Bitter (późniejszy wiceprzewodniczący CKŻP z ramienia PPR), Menachem Marek Asz, pisarz Jehuda Elberg, Mieczysław Szpecht i Ada Lichtman. Celem Komisji było „stworzenie jak największej liczby materiałów dla historii”7. Jak czytamy w protokole pierwszego posiedzenia, wyrażano obawy, że „rezultat pracy Komisji może wydawać się nieważny, ale w przyszłości zrozumiemy, jak ważne będą stworzone już materiały"8. Notabene, protokołowanie relacji osób zgłaszających się do Komitetu Żydowskiego rozpoczęło się na kilka dni przed jej formalnym powołaniem; jedna z pierwszych zachowanych w archiwum ŻIH relacji została spisana 20 sierpnia 1944 roku . Z kolei 28 sierpnia Eda Lieberman spisuje opowieść krawca Pereca Szapiry ${ }^{10}$. Relacja ta, dotycząca losu Żydów z Gniewoszowa oraz obozu pracy w Dęblinie, pokazuje dwa interesujące zagadnienia. Pierwsze $\mathrm{z}$ nich to fakt, w jakich okolicznościach je spisywano; Szapiro pięć dni wcześniej „wraz z 11 pracownikami żydowskimi uciekł z obozu pracy. Przy życiu jednak pozostali dwa chłopcy, opowiadający i Bleichman Szja z Ryk, ur. 1926. Resztę uciekających zabił ktoś z ludności miejscowej"11. Drugi zaś to problem z nadaniem formalnych ram relacji, ustandaryzowaniem jej dla celów Komisji. Już na pierwszym zebraniu ŻKH opracowała schemat ankiety, zawierający trzynaście punktów i ułożonych w porządku chronologicznym - od wkroczenia Niemców, pierwszych represji, tworzenia gett poprzez „oznaki oporu”, likwidację gett i Zagładę, aż do ukrywania się i wyzwolenia. Zwracano również uwagę na „stosunek miejscowej ludności". Co ciekawe, nie pojawia się tu pytanie o obozy zagłady. Personalia były pierwszym punktem w ankiecie - również relacja Szapiry zawiera metryczkę dotyczącą danych osobistych autora (data i miejsce urodzenia, zawód). Ale wywiadom starano się również nadać formalne ramy dokumentu; stąd pojawia się tu słowo „protokół” oraz podpis protokolantki. Szapiro jednak „opowiada”, nie „zeznaje”. Komisja używa tu słowa „wspomnienia”, zaś

7 AŻIH, Centralna Żydowska Komisja Historyczna, sygn. 303/XX/10, Protokół z posiedzenia Żydowskiej Komisji Historycznej z 29 VIII 1944, k. 1-3, przeł. O. Pieńkowska. Bardzo dziękuję tłumaczce za udostępnienie przekładu.

8 Tamże.

9 Relacja Gerntera (imię nieznane) dotycząca likwidacji gett w Sandomierzu i Staszowie. AżıH, , Relacje, sygn.301/13.

10 AŻıH, Relacje, sygn. 301/8.

11 Tamże, k. 5 
spisujący to "protokolanci” i „zbieracze”12. To ostatnie słowo bezpośrednio odwołuje się do tradycji zamlerów i dokumentowania losów ludności żydowskiej, zwłaszcza narracji o prześladowaniach. Świadek zaś w protokołach Komisji to „petent” ${ }^{\prime \prime}$. Sięgnięto tu więc po język urzędniczy.

Zbieranie wspomnień od początku było zakrojone na szeroką skalę - planowano stworzenie sieci korespondentów w różnych miastach, protokółujących relacje osób zgłaszających się do Komitetów Żydowskich. W początkowej fazie przewidziano nawet kary dla osób w postaci odmowy udzielenia pomocy materialnej, co znalazło swoje odzwierciedlenie w protokole ŻKH z 1 września 1944: „należy zaprosić Żydów, którzy przeszli obozy w Treblince, Majdanku i Sobiborze, żeby przekazali swoje wspomnienia; w przypadku jeśli nie będą chcieli przyjechać, należy zastosować sankcje”. Należy podkreślić, że zbierających interesowały ogólnie losy Żydów, nie zaś ocalałych z konkretnych obozów. Powyższa wzmianka wskazuje jednak, że do relacji tych, którzy na własne oczy widzieli Zagładę w komorach gazowych, przykładano największą wagę.

Te wszystkie założenia zostaną doprecyzowane i rozwinięte po przekształceniu ŻKH w Centralną Żydowską Komisję Historyczną 15 grudnia 1944 roku (oficjalne zebranie założycielskie odbyło się 29 grudnia), a zwłaszcza po przeniesieniu siedziby Komisji w lutym 1945 roku z Lublina do Łodzi. Przewodniczącym CŻKH zostaje dr Filip Friedman, który w dokumencie programowym Cele i zadania Centralnej Żydowskiej Komisji Historycznej pisał, że powstała ona „dla poinformowania opinii świata, który zna cyfry globalne mordów hitlerowskich, ale nie zdaje sobie jednak sprawy z tego, że cyfry te to jeszcze nie wszystko" ${ }^{4}$. Stąd celem Komisji jest „zebrać wszelkie akta i dokumenty, pozostawione przez niemieckie władze cywilne, wojskowe i policyjne, dokumenty organizacji i instytucji żydowskich, protokólarne oświadczenia ocalałych ofiar i naocznych świadków zbrodni hitlerowskich, akta sądowe, fotografie, pamiętniki, zapiski, kroniki i wszelkie inne poszlaki i dowody"15. Widać tu znaczące rozłożenie akcentów. Po pierwsze, dowodem Zagłady jest tu nie tylko relacja świadka, a każdy materiał i dowód. Po drugie

\footnotetext{
12 AŻIH, CŻKH, sygn. 303/XX/10, Protokół posiedzenia ŻKH z 1 września, k. 24, przeł. O. Pieńkowska.

13 Tamże.

14 AŻIH, CŻKH, sygn. 303/XX/38, Cele i zadania CentralnejŻydowskiej Komisji Historycznej, k. 24.

15 Tamże.
} 
zaś, zbiera się je nie tylko w celu czysto historycznym, a przede wszystkim, aby można zdać sobie w pełni sprawę „ze skutków straszliwej katastrofy”. Zbierane dokumenty i przedmioty miały być nie tylko - jak pisał Noe Gruss w wydanym w 1946 roku Roku pracy Centralnej Żydowskiej Komisji Historycznej, „wiedzą-pomnikiem"16, ale przede wszystkim materiałem dowodowym. Wyjątkowość Zagłady oznaczała potrzebę dokumentowania i przekazywania informacji w zupełnie nowym, ważnym kontekście. Relacje osób, które przeżyły Zagładę, miały bowiem nie tylko rangę świadectwa, lecz także aspekt prawny zeznania, a więc dowodu. „To, co obecnie zostanie napisane, powinno być aktem oskarżenia" - pisał Friedman, mając na myśli nie tylko metaforyczny, ale i całkiem dosłowny akt oskarżenia. Wydawane przez CŻKH Instrukcje ${ }^{\mathbf{1 7}}$ dla zbierających relacje pokazują wyraźnie, że mimo interdyscyplinarności i gromadzenia różnego rodzaju dowodów w centrum zainteresowania znajdował się właśnie świadek - zeznający - i jego doświadczenie. Jego relacja miała być przede wszystkim podstawowym materiałem źródłowym „do zrekonstruowania aktu oskarżenia przeciwko całemu narodowi niemieckiemu i poszczególnym znanym z nazwiska i imienia Niemcom, którzy brali udział w dziele zbrodni, wreszcie przeciwko tym wszystkim, którzy okryli się hańbą współdziałania z Niemcami"18. Dopiero później zeznanie stawało się „źródłem do badania dziejów żydowskich"19, które należało opracować historycznie. Nie zakładano także przeprowadzania wywiadów ze wszystkimi zgłaszającymi się do Komisji Historycznej - „Przesłuchać należy ludzi, którzy mają coś nowego do dodania, posiadają konkretne informacje, lub uzupełniają posiadane już przez nas"20.

Stąd relacje stają się „zeznaniami ocalałych Żydów”, co do dziś jest podtytułem zbioru 301. Słowa „wywiad” i „zeznanie” występują tu naprzemiennie, z rzadka pojawia się nawet „przesłuchanie”. Język urzędniczy z pierwszych

16 N. Grüss Rok pracy Centralnej Żydowskiej Komisji Historycznej, Centralna Żydowska Komisja Historyczna, Łódź 1946, s. 10.

17 Instrukcje dla zbierania materiałów historycznych z okresu okupacji niemieckiej, Instrukcje dla zbierania materiałów etnograficznych z okresu okupacji niemieckiej, Instrukcje dla badania przeżyć dzieci żydowskich w okresie okupacji niemieckiej, CKŻP Komisja Historyczna, Wydawnictwo CŻKH, Łódź 1945 . Instrukcje dla zbierania materiałów historycznych z okresu okupacji niemieckiej, CKŻP Komisja Historyczna, Łódź 1945 Tamże, s. 7. List F. Friedmana do WKH w Przemyślu z 21 maja 1945, AŻIH, CŻKH, sygn. 303/XX/384. 
relacji zbieranych $\mathrm{w}$ Lublinie zastąpiony zostaje prawnym; na narrację świadka nałożono poetykę i ramy zeznania sądowego, a częścią składania relacji było zaś jej odczytanie i podpisanie przez świadka ${ }^{21}$. Pokazuje to np. metryczka relacji Róży Nass, spisanej w Wojewódzkiej Żydowskiej Komisji Historycznej w Krakowie 24 października $1946 \mathrm{roku}^{22}$. Nosi ona tytuł „protokół zeznania złożonego przed WŻKH”, które „odbiera” Maria Holender. Świadek jest tu „zeznającą", która swoją relację potwierdza własnoręcznym podpisem - w wielu innych dokumentach ze zbioru 301 znaleźć można również podpis protokolanta/protokolantki potwierdzający prawdziwość tegoż podpisu. Niekiedy dodawana jest również formułka „Po odczytaniu mi protokołu potwierdzam zgodność takowego ze złożonym zeznaniem" oraz podkreślanie, że „podany materiał oparty jest na osobistej obserwacji”"23. Zgodnie z zaleceniami zawartymi w opracowanej przez Friedmana i Józefa Kermisza Instrukcji dla zbierania materiałów historycznych $z$ okresu okupacji niemieckiej do wielu zeznań dołączano „charakterystykę świadka”. Lusię Mehr, składającą własnoręcznie przepisaną na maszynie relację 28 lipca 1947 roku we Wrocławiu, scharakteryzowano następująco: „Bardzo wrażliwa i przeżywa przy opowiadaniu. Twierdzi, że wszystko co opowiada jest tylko małą cząstką jej przeżyć. Wszystkiego nie jest w stanie wyrazić słowami. Niemcy pisze przez małe «n» wyrażając w ten sposób pogardę dla morderców" ${ }^{24}$. Z kolei spisująca 28 sierpnia 1947 roku relację czternastoletniego wówczas Selmana Birnfelda Janina Sobol-Masłowska z WKH w Katowicach napisała w uwagach: „Zeznający prawdomówny, kochający gospodarkę, życie na wsi. Obecnie nie czuje się dobrze, tęskni za życiem na wsi"25.

Mimo jednak wytycznych zawartych w Instrukcjach, założeń i języka prawnego, relacje zbierane przez CŻKH utrzymane są w różnej poetyce - od swobodnie snutych, wręcz momentami poetyckich opowieści, poprzez suche relacjonowanie faktów aż do stenograficznego zapisu wypowiedzi. Często dotyczą one pojedynczego wydarzenia lub przeżyć w danym miejscu, nie

21 N. Grüss Rok pracy..., s. 9.

22 AŻlH, Relacje, sygn. 301/2020.

AŻıH, Relacje, sygn. 301/313.

AŻIH, Relacje, sygn.301/2522.

25

AżIH, Relacje, sygn. 301/3512. Birnfeld przeżył wojnę, najmując się jako pomoc do gospodarstwa i pastuch bydła na wsiach w okolicach Rzeszowa; w 1947 roku trafił do Domu Dziecka w Chorzowie. 
są zaś rekonstrukcją całości losów podczas okupacji. W przypadku relacji spisanych przez protokolanta/protokolantkę (w odróżnieniu od tych sporządzanych własnoręcznie przez świadków) często mamy do czynienia również ze streszczeniem zeznania (w trzeciej osobie), nie transkrypcją - z reguły nie zachowywano swoistości wypowiedzi czy narracji pierwszoosobowej. Były jednak wyjątki - szczególny nacisk kładziono na relacje dziecięce, zgodnie z zaleceniami spisywanych - w miarę możliwości - słowo w słowo. Przykładem może być tu opis przeżyć Sali Stajnwurcel, rocznik 1938, spisany 27 marca 1947 roku przez Noe Wertzchajzera z WKH w Wałbrzychu: „Mamusia poszła z braciszkiem do Chełma, a my poszliśmy przez łąki do lasu. Tu byliśmy jeden dzień, w rowie. Tam było dużo zwierząt i my baliśmy się. Rano przyszedł pastuch krów i zobaczył nas. Tatuś dał mu pieniądze i kostki cukru i prosił, żeby nie wydał nas. Ale baliśmy się, że on może opowiedzieć i wieczorem poszliśmy dalej. Byliśmy u jednego człowieka, nazywał się Amruż. Był on biedny i miał głupią żonę"26. Ta wierność zapisu była zgodna z wytycznymi Noe Grussa z Instrukcji dla badania przeżyć dzieci żydowskich w okresie okupacji niemieckiej, według których szczególny nacisk w zbieraniu narracji dziecięcych kładziono na emocje, „sposób przeżywania”, który miał być ważniejszy niż „treść opowiedzianego przeżycia"27. „Przebieg bowiem wypadków, fakty zbrodni, sposoby mordowania, znamy już z zeznań dorosłych, którzy opowiadają o tym [o] wiele dokładniej. Przeprowadzając badania dzieci, zdajemy sobie z góry sprawę z tego, że one mogą posiadać mniejszą wartość dowodową, ale nieocenioną wprost wartość psychologiczną"28. W relacjach dorosłych emocje również się pojawiają, ale dla celów dowodowych rzeczywiście bardziej liczą się - oprócz faktów - nazwiska i miejsca, co widać nie tylko po samej treści, ale chociażby po podkreśleniach pracowników Komisji w spisanym tekście. Informacje te trafiały potem do kartotek sporządzanych w CŻKH.

Kluczowa dla zbieranych relacji i samego świadka/zeznającego jest jednak kategoria naoczności i osobistego doświadczenia. Friedman i Kermisz w opracowanej przez siebie Instrukcji pisali: „Podkreślamy raz jeszcze, że najcenniejszym w zeznaniach będzie zawsze to, co świadek sam widział i przeżył"29. Osobistość doświadczenia jest tutaj kluczem i nie jest podważana,

\footnotetext{
26 AŻlH, Relacje, sygn. 301/2282, k. 2.

27 Instrukcje dla badania przeżyć dzieci żydowskich w okresie okupacji niemieckiej, s. 7.

28 Tamże.

29 Tamże, s. 8.
} 
nawet jeśli z uwag protokolanta wynika, że ma on wątpliwości co do faktografii lub szczegółów. Uwagi te są dodawane do relacji, ale jako post scriptum. Ilustracją takiego przypadku jest relacja Estery Rubinsztajn, spisana przez Klarę Mirską 15 września 1945 roku w Łodzi. Rubinsztajn ukrywała się m.in. w Warszawie u niejakiej pani Dubieckiej (Grubeckiej) na Madalińskiego, gdzie przeszła załamanie nerwowe i miała ataki furii. W uwagach Mirska dopytuje świadka „jak gospodyni w Warszawie [...] nie bała się ją przechowywać, gdyż miewała ataki furii i krzyczała” i notuje odpowiedź, że „ją wiązano, a krzyk jej nie dochodził do uszu niepowołanych, gdyż była to zima i okna były szczelnie zamknięte" ${ }^{\prime 30}$. Mimo swoich wątpliwości protokolantka nie podważa prawdziwości relacji i dodaje, że „jeszcze teraz świadek przeżywa wiele, gdy opowiada o swoich przejściach. Poznać, że ją te opowiadania męczą, że są to wszystko prawdziwe przeżycia, które do dziś dnia wywołują wstrząs" ${ }^{\text {"31 }}$. Ostatecznie więc wiarygodność świadka zależy od spisującego/spisującej relację, o czym jeszcze będzie mowa. Co zaś do naoczności, to świadkowie często ją podkreślają, używając oprócz wyrazu „widziałem” fraz takich jak „W mojej obecności zdarzyło się ${ }^{\text {"32 }}$, „mogłam przypatrywać się dantejskim scenom" ${ }^{33}$ lub „widoku, który mi się przedstawił [...] nie zapomnę chyba przez całe moje życie" ${ }^{\prime 34}$. Niekiedy też wskazują w relacjach nazwiska tych, którzy mogą potwierdzić ich słowa; przykładem może tu być relacja Antoniego Słomczykowskiego, spisana 24 czerwca 1947 roku przez CŻKH w Łodzi. Słomczykowski opisuje egzekucję Żydów na Łagiewnikach w 1939 roku i miejsce, gdzie pochowano zastrzelonych, dodając "Również moja żona i córka mogą potwierdzić, że widziały tabliczkę nad prowizorycznym grobem na miejscu stracenia. Widziały również, że ciała były płytko pochowane, gdyż nogi ofiar wystawały"35. Naoczność pojawia się także w zeznaniach spisywanych w trzeciej osobie. Ilustracją może być tu relacja Zuzanny Kuczerowej z września 1946 roku, zaprotokołowana przez Mendla Turka z WKH w Białymstoku, dotycząca rabunku grobów w Pietraszach: „Świadek zeznaje, że idąc po drewno do palenia zauważyła, że ludzie odkopują groby [...] Żydów. [...] Świadek naocznie

AŻIH, Relacje, sygn. 301/1013, k. 15.

Tamże.

AŻIH, Relacje, sygn. 301/285, k. 4.

AŻlH, Relacje, sygn. 301/1089, k.1.

N.N., AŻIH, Relacje, sygn. 301/204, k. 3.

AŻlH, Relacje, sygn. 301/2506, k. 9. 
widziała, jak wyjmowali złote zęby, zdejmowali obuwie. Odkopanych przysypywali ziemią. Świadek zeznaje, że złote zęby i obuwie sprzedawali na rynku albo zamieniali na masło, słoninę i inne produkty" ${ }^{\prime 36}$.

Wracając do problemu, że o wiarygodności świadka i świadectwa decyduje protokolant poprzez uwagi i sporządzaną charakterystykę zeznającego, w przypadku relacji zbieranych przez CŻKH stwarza to interesujący paradoks, sygnalizowany już przez wywiad przeprowadzany przez Stefanię Beylin z Esterą Bieżuner - otóż świadka Zagłady wysłuchuje również świadek. Część protokolantów CŻKH była Żydami, którzy przeżyli w podobnych okolicznościach; reszta, która spędziła wojnę w ZSRR, również miała doświadczenie utraty bliskich. Tej szczególnej perspektywy nie ignorowano i zdawano sobie z niej sprawę; „pracownicy Komisji stanęli przed zupełnie specyficznymi zadaniami; ich celem było zbadanie najnowszego okresu wypadków, których byli sami naocznymi świadkami, trudno było o obiektywizm, którego wymagają badania historyczne" ${ }^{\text {"37 }}$. Mimo że zbieracza porównywano do protokolanta sądowego ${ }^{38}$, wiedziano, że nie jest bezstronny, a wręcz podkreślano, że znajomość „badanej rzeczywistości” pozwalała na głębsze zrozumienie zeznającego ${ }^{39}$. Dla wielu protokolantów była też to swoista forma terapii, o czym świadczą wspomnienia Janiny Sobol-Masłowskiej: „Wszyscy pracują z wielkim oddaniem, cieszą się każdym dokumentem jak skarbem. Przeżyli gehennę hitlerowską, stracili swoich najbliższych i w tej ciężkiej pracy znaleźli ukojenie" ${ }^{\text {"40 }}$. Niekiedy jednak przeżycia świadków nawet dla protokolantów były zbyt obciążające i prowadziły do swoistej cenzury zeznań, czego przykładem może być dopisek Blanki Lewin z WKH w Lublinie do wspomnień Heli Arbeiter spisanych w 1945 roku: „Wspomnienia pisane nieudolnie zawierają jednak tyle momentów zgrozy, żeśmy uważali za stosowne umieścić je in extenso"41. Jak się jednak wydaje, cenzurowanie relacji było dość rzadkie.

Świadkami więc są tu wszyscy - ale istotny jest moment, kiedy świadek staje się zeznającym, jest wywołany do dania świadectwa. Tu znów trzeba zwrócić uwagę na prawny wymiar świadectw zbieranych przez CŻKH.

36 AŻıH, Relacje, sygn. 301/2008, k. 1.

37 AŻıH, CŻKH, sygn. 303/XX/26, Sprawozdanie CŻKH za maj 1945 roku, k. 44.

38 Instrukcje dla zbierania materiałów historycznych z okresu okupacji niemieckiej, s. 8.

39 Tamże.

40 J. Sobol-Masłowska Fakty i wspomnienia, cz. I, Ayalon, Hajfa 1972, s. 152.

41 AŻ̇H, Relacje, sygn. 301/272, k. 2 
Rzeczywiście, stawały się one częścią aktów oskarżenia i procesów - CŻKH pełni funkcję pomocniczą przy dochodzeniach prokuratury, Głównej Komisji Badania Zbrodni Nazistowskich i procesach zbrodniarzy przed Naczelnym Trybunałem Narodowym. Komisja wskazywała świadków, przygotowywała materiały i sporządzała ekspertyzy; niekiedy, jak w przypadku Chełmna nad Nerem, przeprowadzano wywiady, które były opatrzone nagłówkiem „Protokół przesłuchania"42. Filip Friedman, przewodniczący CŻKH i ekspert NTN, uczestniczył w procesie w Norymberdze, na który CŻKH przygotowała część materiałów mających służyć jako dowody polskim prokuratorom i wydrukowała broszurkę Deutsche Verbrechen gegen die jüdische Bevölkerung in Polen 1939-1945. Pracownicy Komisji oraz WŻKH na bieżąco sporządzali ekspertyzy na procesy zbrodniarzy hitlerowskich przed NTN oraz w innych sądach, a także występowali jako świadkowie; dużą rolę materiały CŻKH i wskazani przez Komisję świadkowie odegrali w procesach Amona Götha, Ludwiga Fischera czy Josefa Bühlera. Prowadzono też obfitą korespondencję z sądami w sprawie ścigania zbrodniarzy hitlerowskich, opierając się na sporządzanych m.in. dzięki zebranym relacjom kartotekach przestępców.

W ciągu trzech lat działalności ŻKH/CŻKH zgromadzono 3 tysiące zeznań. Ich analiza wskazuje wyraźnie, że świadectwo jest nie tylko osobistym zapisem losów, który staje się historycznym materiałem źródłowym, ale narracją prawną, zeznaniem, które może posłużyć do oskarżenia winnych. Świadkami są i opowiadający, i ci wysłuchujący oraz spisujący ich opowieść - żadna ze stron nie jest bezstronna i obiektywna. Kluczowa jednak jest przemiana relacji w zeznanie, poświadczone podpisem, uwiarygodnione przez naoczność i osobiste doświadczenie, ale przede wszystkim przez protokolanta i jego uwagi oraz sporządzoną przez niego charakterystykę. Prawdomówności, podanych faktów czy dat jednak z reguły się nie podważa - to zadanie historyka albo sądu. Świadek więc jest tu powoływany do roli zeznającego, nadawany jest mu status nie tylko mający wymiar historyczny, ale przede wszystkim prawny. Osobista narracja staje się oskarżeniem w sensie dosłownym i prawnym - może ona być użyta w sądzie. Takie spojrzenie na świadka i świadectwo wnosi interesującą perspektywę do współczesnych rozważań na ten temat - świadkami bowiem są wszyscy, ale podlegają aktowi ustanowienia, nadaniu statusu zeznającego. Opowieść o przeżyciach to nic innego jak stanięcie pośrodku sali sądowej przy pulpicie, nadana rola - a miejsce to może zająć każdy - świadek, protokolant, a także sędzia. Świadectwo

42 Np. AŻIH, Relacje, sygn. 301/5350, Protokół przesłuchania Andrzeja Miszczaka. 
zostaje podniesione do rangi zeznania i staje się dowodem - nie tylko dla sądu, ale i dla świata. I - oprócz zbieranych przez Centralną Żydowską Komisję Historyczną innych dowodów, takich jak dokumenty, zdjęcia, przedmioty czy szczątki ludzkie - staje się najważniejsze dzięki swojej formie zeznania, osobistej, nieopracowanej przez historyka opowieści. Jak pisał Beniamin Mosiężnik w Zadaniach i pracach CŻKH, „naukowe sformułowania nie wyrażą bowiem i nie utrwalą tego, co w tym wszystkim było najbardziej istotne: tragicznej treści człowieczej”43.

\section{Abstract}

\section{Agnieszka Haska}

INSTITUTE OF PHILOSOPHY AND SOCIOLOGY OFTHE POLISH ACADEMY OF SCIENCES

Evidence and Witnessing: Testimonies of the Holocaust in the Early Post-War Era

Haska discusses the moment when the narrative about being a witness of the Holocaust emerged. She analyses accounts collected by the Central Jewish Historical Commission in the years 1944-1947, currently kept at the archive of the Jewish Historical Institute under number 301 . This collection clearly shows that the testimony was treated as a legal narrative, as a witness account that could be used to accuse perpetrators. The article discusses the different dimensions of the testimony, such as the question of being an eyewitness and the way the protocol-maker, who is also a witness, establishes credibility. The minute secretary is also called upon to testify - both in a metaphorical as well as legal sense.

\section{Keywords}

Holocaust, Central Jewish Historical Commission, witness accounts 